\title{
Biochemical Genetic Variations in Black Seabrem
}

\author{
Komar Sumantadinata* and Nobuhiko Taniguchi* \\ (Received July 13, 1981)
}

\begin{abstract}
The samples of three lots of black seabream Acanthopagrus schlegeli (BLEEKER) collected from the coastal waters of Okayama, Osaka, and Aichi were used for the screening of polymorphism in eighteen enzymes, sarcoplasmic proteins, and hemoglobins. Among 44 loci examined, 16 loci of the ten enzymes and sarcoplasmic proteins were polymorphic. The observed numbers of phenotypes in respective loci well agreed with the Hardy-Weinberg expectations. The genetic model of each polymorphic enzyme was discussed. Most of the polymorphic loci were dimer, except for phosphoglucomutase, esterase-2, sarcoplasmic protein-1, and sarcoplasmic protein-2 which were monomer, and sarcoplasmic protein -3 which was tetramer.

The genic variability in this species was relatively high compared with other marine fishes. According to the chi-square values for heterogeneity between two locations, Okayama was considered to be different from the other two locations. Based on the low values in F-statistics $\left(F_{S T}\right)$ and genetic distance (D), we concluded that the differentiation among localities was very small.
\end{abstract}

In recent years, mariculture in Japan has been making a rapid progress. The black seabream Acanthopagrus schlegeli (BlEEKER), is one of the important marine fish cultivated widely. Artificial breeding of this species has been applied successfuly for fish seed mass production. The fish seed has been used not only for stocking of the cage culture, but also for releasing to the natural waters for conservation of the sea resources.

Electrophoresis of various proteins or enzymes has been applied to biological research of both basic and applied interests. ${ }^{1)}$ In Japan, the electrophoretic method has been widely used for genetic population study of some freshwater fish, marine fish, and anadromous fish. Since MoAv et $a .^{2}{ }^{2}$ proposed to use the electrophoretic genetic markers to fish breeding study, these markers were applied for the breeding study of common carp Cyprinus carpio, ${ }^{3-4}$ ) coho salmon Oncorhynchus kisutch, ${ }^{3)}$ and nibe croaker Nibea mitsukurii, and red seabream Pagrus major. ${ }^{\circ}$ )

In this study, the electrophoretic patterns of polymorphic enzymes and proteins examined in black seabream will be shown using three lots of samples collected from the coastal waters of Okayama, Osaka, and Aichi. The results may be important as the basic knowledge for the future development in the breeding study of this species.

\section{Materials and Methods}

Black seabream samples were collected from the coastal waters of Okayama Pref. (80 specimens), Osaka Pref. (32 specimens), and Aichi Pref. (72 specimens) during August to November 1980. The fish samples were stored at $-20^{\circ} \mathrm{C}$ until used. The skeletal muscle, liver, heart, and eye were dissected for electrophoretic analysis. The preparation of enzyme and protein samples and horizontal starch-gel electrophoretic procedures are given by TANIGUCHI and NUMACHI. ${ }^{\text {() }}$ Two buffer systems used were tris-citric acid (T-C) pH 8.0 and citric acid-aminopropylmorpholine (C-APM) pH 6.0.

The enzymes examined here were as follows: Adenylate kinase (AK, E.C. 2.7.4.3), alcohol dehydrogenase (ADH, E.C. 1.1.1.1), aspartate aminotransferase (AAT, E.C. 2.6.1.1), creatine kinase (CK, E.C. 2.7.3.2), esterase (EST, E.C. 3.1.1.3), fumarate hydratase (FH, E.C. 4.2.1.2), glucose-6-phosphate dehydrogenase (G-6-PDH, E.C. 1.1.1.49), glutamate dehydrogenase (GuDH, E.C. 1.4.1.2), glucosephosphate isomerase (GPI, E.C. 5.3.1.9), $\alpha$-glycerophosphate dehydrogenase ( $\alpha-\mathrm{GDH}$, E.C. 1.1.1.8), D(-)3-hydroxybutyrate dehydrogenase (HBDH, E.C. 1.1.1.30), isocitrate dehydrogenase (IDH, E.C. 1.1.1.42), lactate dehydrogenase (LDH, E.C. 1.1.1.27), malate dehydrogenase (MDH, E.C. 1.1.1.37), malic enzyme (ME, E.C. 1.1.1.40), phosphoglucomutase (PGM, E.C. 2.7.5.1), 6-phosphogluconate dehydrogenase (6-PGD, 1.1.1.44), and sorbitol dehydrogenase (SDH, E.C. 1.1.1.14). The list of enzymes and proteins, tissue assayed, buffer systems used, and

* Department of Cultural Fisheries, Faculty of Agriculture, Kochi University, Nankoku, Kochi 783 ( $\neg \nabla$ ル・スマンタディナタ・谷口順彦：高知大学農学部栽培漁業学科)。 
Table 1. The list of enzymes and proteins examined, organs assayed, buffer systems used, and references for staining method

\begin{tabular}{|c|c|c|c|}
\hline Enzyme and protein & Organ & Buffer & Staining method \\
\hline Adenylate kinase (AK) & Heart & C-APM & SHAW and PraSAD ${ }^{8)}$ \\
\hline Alcohol dehydrogenase (ADH) & Liver & $\mathrm{T}-\mathrm{C}$ & TANIGUCHI et al..$^{10)}$ \\
\hline Aspartate aminotransferase (AAT) & Muscle & C-APM & TANIGUCHI and NUMACHI \\
\hline Creatine kinase $(\mathrm{CK})$ & Liver & C-APM & SHAW and PRASAD ${ }^{9)}$ \\
\hline Esterase (EST) & Liver & $\mathrm{T}-\mathrm{C}$ & SHAW and Prasad ${ }^{\theta)}$ \\
\hline Fumarate hydratase $(\mathrm{FH})$ & Muscle & $\mathrm{T} \cdot \mathrm{C}$ & SHAW and PrasaD ${ }^{9)}$ \\
\hline $\begin{array}{l}\text { Glucose-6-phosphate dehydrogenase } \\
\text { (G-6-PDH) }\end{array}$ & Muscle & $\mathrm{T}-\mathrm{C}$ & SHAW and PRASAD ${ }^{\theta)}$ \\
\hline Glucosephosphate isomerase (GPI) & Muscle, heart & C-APM & SHaw and Prasad ${ }^{6)}$ \\
\hline Glutamate dehydrogenase (GuDH) & Liver & $\mathrm{T}-\mathrm{C}$ & ShaW and Prasad ${ }^{0}$ ) \\
\hline $\begin{array}{l}\alpha \text {-Glycerophosphate dehydrogenase } \\
(\alpha-\text { GDH })\end{array}$ & Muscle, liver & $\mathrm{T} \cdot \mathrm{C}$ & NUMACHI $^{11)}$ \\
\hline Hemoglobin (HEM) & Blood & C-APM & Amido black $10 \mathrm{~B}$ \\
\hline $\begin{array}{l}\mathrm{D}(-) \text { 3-hydroxybutyrate dehydrogenase } \\
\text { (HBDH) }\end{array}$ & Liver & $\mathrm{T}-\mathrm{C}$ & SHAW and PRASAD ${ }^{\theta)}$ \\
\hline Isocitrate dehydrogenase (IDH) & Muscle, liver & C-APM & TANIGUCHI and NUMACHI ${ }^{z}$ ) \\
\hline Lactate dehydrogenase (LDH) & $\begin{array}{l}\text { Muscle, heart, } \\
\text { eye }\end{array}$ & $\mathrm{T}-\mathrm{C}$ & NumaChI ${ }^{1.1}$ \\
\hline Malate dehydrogenase (MDH) & Muscle & $\mathrm{T}-\mathrm{C}$ & NUMACHI ${ }^{11)}$ \\
\hline Malic enzyme (ME) & Muscle, heart & $\mathrm{T} \cdot \mathrm{C}$ & AyAlA et al. ${ }^{12)}$ \\
\hline Phosphoglucomutase (PGM) & Liver & C-APM & Shaw and Prasad ${ }^{g}$ \\
\hline $\begin{array}{l}\text { 6-Phosphogluconate dehydrogenase } \\
\text { (6-PGD) }\end{array}$ & Liver & C-APM & SHAW and PRASAD ${ }^{9}$ \\
\hline Sarcoplasmic protein (SP) & Muscle & $\mathrm{pH} 3.5-9.5$ & LUNDSTROM $^{13)}$ \\
\hline Sorbitol dehydrogenase (SDH) & Muscle, liver & $\mathrm{T}-\mathrm{C}$ & ShaW and PRASAD ${ }^{\theta}$ \\
\hline
\end{tabular}

T-C: tris-citric acid pH 8.0.

C-APM: citric acid-aminopropyl morpholine pH 6.0 .

staining references are presented in Table 1.

Isoelectric focusing was applied to the special separation of sarcoplasmic protein. For the materials and procedure of isoelectric focusing see TANIGUCHI et $a l^{\text {s) }}$

\section{Results and Discussion}

\section{Polymorphism and Its Genetic Control}

Eighteen enzymes, sarcoplasmic proteins, and hemoglobins (Table 1) encoded by 44 loci were examined by electrophoretic method. Among 44 loci, 16 loci were polymorphic. The remaining 16 loci of enzymes, 9 loci of sarcoplasmic proteins, and 3 loci of hemoglobins were monomorphic. Diagramatic representation of relative electrophoretic mobility of the polymorphic enzymes are provided in Fig. 1. The brief description of the polymorphic enzymes are as follows:

$A D H$ : This enzyme moved to the cathodal zone which is considered to be controlled by three alleles of one locus. The heterozygous type has three bands, so that the protein structure should be a dimer in sub-unit composition. The slower and the faster homozygous types and type $\mathrm{AC}$ did not appear in all of the samples examined.

$C K$ : The one locus with two alleles model was presumed for this enzyme which appeared in the anodal zone. The heterozygous type has three bands and the homozygous one band. No fast homozygous band (phenotype $\mathrm{A}$ ) was detected in the samples tested this time.

EST: Esterase enzyme appeared in the anodal zone which supposed to be consisted of two loci, namely Est-1 and Est-2. Each locus has two bands for heterozygous type and one band for homozygous type, so that these two loci must be a monomer. Since one band (phenotype $C$ ) of Est -1 was located in the Est-2 zone, it was rather difficult to distinguish the phenotypes $\mathrm{C}, \mathrm{CB}$, and CA from each other. The banding pattern of Est-1 indicated that this locus is controlled by three alleles, and Est-2 locus by two alleles.

$\alpha-G D H:$ Two loci were detected in this enzyme, liver specific isozyme $(\alpha-G d h-1)$ and muscle specific isozyme $(\alpha-G d h-2)$ which both appeared in the anodal zone. The $\alpha-G d h-1$ locus was presumed to be controlled by three alleles, and $\alpha-G d h-2$ by two alleles. The heterozygous type of both locus has three bands, so that this enzyme 


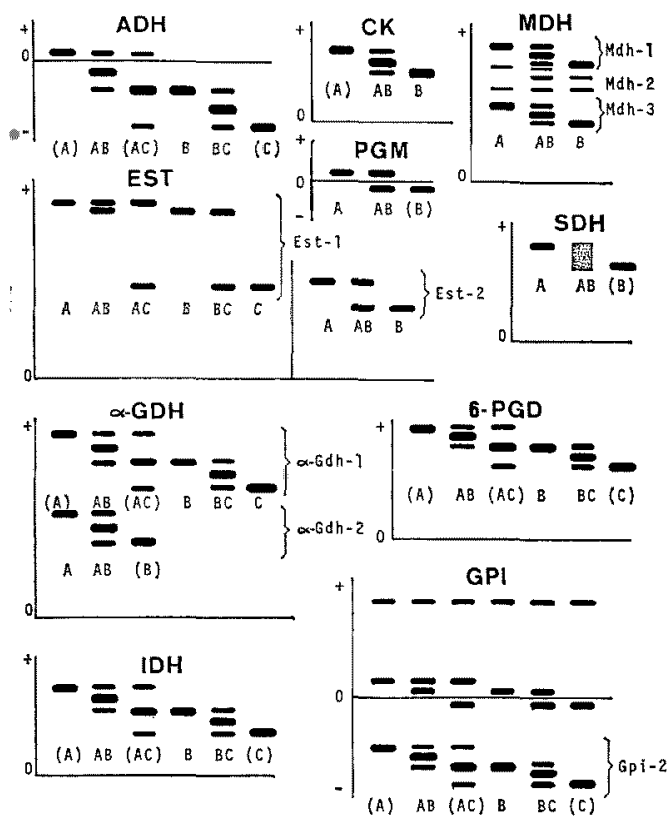

Fig. 1. Isozyme patterns of polymorphic enzymes in black seabream. As for the SP pattern see TANiguchi et al. ${ }^{8)}$ Phenotypes in parenthesis were not yet found. The start line is shown by " $\mathrm{O}$ ".

may be dimeric in protein structure.

$I D H$ : This enzyme was encoded by three alleles of one locus in the anodal zone. The heterozygous type has three bands, so that this enzyme should dimeric in sub-unit composition. The phenotypes $\mathrm{A}, \mathrm{AC}$ and $\mathrm{C}$ were not yet detected in all of the samples examined here.

MDH: This enzyme was detected in the anodal zone, and consisted of three loci named $M d h$-1, $M d h-2$, and $M d h-3$. Polymorphism was found at $M d h-1$ and $M d h-3$ loci, and each locus has three alleles type. The heterozygous type has three bands as dimeric structure in sub-unit composition.

6-PGD: The relative mobility and genetic model of 6-PGD were more or less similar to IDH.

PGM: This enzyme was controlled by two alleles. The heterozygous type showed two bands, so that this enzyme should be monomeric in molecule structure. Under the electrophotetic conditions applied, one band of heterozygous type was located in the anodal zone and the other in the cathodal zone, very near the origin.

GPI: There were two loci of GPI, Gpi-1 in the anodal zone and $G p i-2$ in the cathodal zone. The bands appearing near the origin was located in the middle zone between Gpi-1 and Gpi-2 and supposed to be heterodimer. Gpi-1 was a nonpolymorphic locus, but $G p i-2$ was polymorphic under the control of three alleles with banding pattern as dimeric structure.

SDH: The polymorphism of SDH enzyme was detected in the liver, and appeared as one locus controlled by two alleles. Under the electrophoretic conditions used, we could not ascertain the band number of heterozygous type.

$S P$ : Three loci in sarcoplasmic isoelectric focusing pattern were polymorphic loci, namely $S p-1, S p-2$, and $S p-3$. The $S p-1$ locus was of a monomeric structure. The $S p-2$ also was presumed to be a monomeric structure, but has an unusual number of band: the homozygous type has two bands and the heterozygous type has four bands. The heterozygous type of $S p-3$ locus has five bands, so that this locus was considered to be related to a tetrameric structure. For the detailed discussion see TANIGUCHI et al ${ }^{\text {B) }}$

The observed number and their HARDYWEINBERG expectation of phenotypes are presented in Table 2. This table also shows the allelic frequencies and chi-square values for the differences between observed and expected number of phenotypes of each polymorphic enzyme and each locality The data in Table 2 indicated that the differences between observed numbers and the HARDY-WEINBERG expectations were not significant at $\mathbf{P}<0.05$ in the respective polymorphic loci examined here. These facts support the validity of the genetic model proposed for each polymorphic enzymes, and suggest that those black seabream samples from each location were collected from the single Mendelian population.

\section{Genic Variability}

The genic variability of black seabream from each locality are presented in Table 3. There was no clear difference on the genic variability among localities, except the small difference which may be due to the difference in sample number. Number of allele per locus ranged from 1.272 in Osaka to 1.386 in Okayama. It was relatively high compared with the ayu, Plecoglossus altivelis ${ }^{14)}$ and nearly similar to the red seabream, Pagrus major. ${ }^{15}$;

The proportion of polymorphic loci ranged from 0.250 to 0.341 (average 0.303). It was higher than some other members of order Percida $^{16)}$ but a little lower than red seabream. ${ }^{153}$ On the other hand the average value of hetero- 
Table 2. Observed number of phenotypes, their HARDY-Wennberg expectations in parenthesis and allelic frequencies at polymorphic loci in black seabream

\begin{tabular}{|c|c|c|c|c|c|c|c|c|c|c|c|c|}
\hline \multirow{2}{*}{ Locus } & \multirow{2}{*}{ Locality } & \multicolumn{6}{|c|}{ Phenotype } & \multirow{2}{*}{$\mathbf{N}$} & \multicolumn{3}{|c|}{ Allelic frequency } & \multirow{2}{*}{$t^{2}$} \\
\hline & & A & $\mathrm{AB}$ & $\mathrm{AC}$ & B & $\mathrm{BC}$ & $\mathrm{C}$ & & $A$ & $B$ & $C$ & \\
\hline \multirow[t]{3}{*}{$A d h$} & Okayama & 0 & 0 & 0 & $\begin{array}{c}78 \\
(78.0)\end{array}$ & $\stackrel{2}{(2.0)}$ & $\begin{array}{c}0 \\
(0.0)\end{array}$ & 80 & 0 & 0.987 & 0.013 & 0.013 \\
\hline & Osaka & $\stackrel{0}{(0.0)}$ & $(1.0)$ & $\begin{array}{l}0 \\
(0.0)\end{array}$ & $\stackrel{30}{(30.0)}$ & $(1.0)$ & $\begin{array}{c}0 \\
(0.0)\end{array}$ & 32 & 0.016 & 0.969 & 0.016 & 0.000 \\
\hline & Aichi & $\begin{array}{l}0 \\
(0.0)\end{array}$ & $(2.0)$ & $\begin{array}{c}0 \\
(0.0) \\
\end{array}$ & $\begin{array}{c}69 \\
(69.0)\end{array}$ & $\begin{array}{l}1 \\
(1.0)\end{array}$ & $\begin{array}{l}0 \\
(0.0)\end{array}$ & 72 & 0.014 & 0.979 & 0.007 & 0.003 \\
\hline \multirow[t]{3}{*}{$C k$} & Okayama & $\begin{array}{l}0 \\
(0.1)\end{array}$ & $\begin{array}{l}4 \\
(3.9)\end{array}$ & 一 & $\begin{array}{c}56 \\
(56.1)\end{array}$ & - & - & 60 & 0.033 & 0.967 & - & 0.071 \\
\hline & Osaka & 0 & 0 & - & 32 & - & 一 & 32 & 0 & 1.000 & - & 0 \\
\hline & Aichi & $\begin{array}{l}0 \\
(0.0) \\
\end{array}$ & $(1,0)$ & 一 & $\begin{array}{c}71 \\
(71.0)\end{array}$ & 一 & 一 & 72 & 0.007 & 0.993 & - & 0.004 \\
\hline \multirow[t]{3}{*}{ Est -1} & Okayama & $\begin{array}{l}51 \\
(50.4)\end{array}$ & $\stackrel{4}{(4.0)}$ & $\begin{array}{l}21 \\
(22.2)\end{array}$ & $\begin{array}{l}0 \\
(0.1)\end{array}$ & $\begin{array}{c}1 \\
(0.9)\end{array}$ & $\stackrel{3}{(2.5)}$ & 80 & 0.794 & 0.031 & 0.175 & 0.294 \\
\hline & Osaka & $\begin{array}{l}19 \\
(18.0)\end{array}$ & $(1.5)$ & $\begin{array}{c}9 \\
(10.5)\end{array}$ & $\begin{array}{c}0 \\
(0.0)\end{array}$ & $\stackrel{1}{(0.4)}$ & $\stackrel{2}{(1.5)}$ & 32 & 0.750 & 0.031 & 0.219 & 1.334 \\
\hline & Aichi & $\begin{array}{c}32 \\
(30.0)\end{array}$ & $\begin{array}{l}5 \\
(6.5) \\
\end{array}$ & $\stackrel{24}{(26.5)}$ & $\begin{array}{l}1 \\
(0.3)\end{array}$ & $\stackrel{3}{(2.8)}$ & $\begin{array}{r}7 \\
(5.8) \\
\end{array}$ & 72 & 0.646 & 0.069 & 0.285 & 2.158 \\
\hline \multirow[t]{3}{*}{ Est -2} & Okayama & $\begin{array}{c}31 \\
(33.8)\end{array}$ & $\begin{array}{l}42 \\
(36.4)\end{array}$ & 一 & $\begin{array}{l}7 \\
(9.8)\end{array}$ & - & - & 80 & 0.650 & 0.350 & - & 1.893 \\
\hline & Osaka & $\stackrel{15}{(14.4)}$ & $\stackrel{13}{(14.1)}$ & - & $\begin{array}{l}4 \\
(3.4)\end{array}$ & - & - & 32 & 0.672 & 0.328 & - & 0.198 \\
\hline & Aichi & $\begin{array}{r}29 \\
(27.3) \\
\end{array}$ & $\begin{array}{l}30 \\
(33.5) \\
\end{array}$ & - & $\begin{array}{l}12 \\
(10.3) \\
\end{array}$ & - & 一 & 71 & 0.620 & 0.380 & - & 0.761 \\
\hline \multirow[t]{3}{*}{$\alpha-G d h-1$} & Okayama & - & - & - & $\begin{array}{c}27 \\
(26,4)\end{array}$ & $\begin{array}{l}11 \\
(12.2)\end{array}$ & $\begin{array}{l}2 \\
(1.4)\end{array}$ & 40 & - & 0.813 & 0.188 & 0.380 \\
\hline & Osaka & - & - & - & $\begin{array}{l}28 \\
(28.1)\end{array}$ & $\left(\begin{array}{l}4 \\
3.8)\end{array}\right.$ & $\begin{array}{l}0 \\
(0.1)\end{array}$ & 32 & - & 0.938 & 0.063 & 0.142 \\
\hline & Aichi & $\begin{array}{l}0 \\
(0.0) \\
\end{array}$ & $\left(\begin{array}{l}1 \\
0.9\end{array}\right.$ & $\begin{array}{l}0 \\
(0.1) \\
\end{array}$ & $\begin{array}{c}54 \\
(55.1) \\
\end{array}$ & $\begin{array}{c}17 \\
(14.9) \\
\end{array}$ & $\begin{array}{l}0 \\
(1.0) \\
\end{array}$ & 72 & 0.007 & 0.875 & 0.118 & 1.469 \\
\hline \multirow[t]{3}{*}{$\alpha-G d h-2$} & Okayama & 80 & 0 & - & 0 & - & - & 80 & 1.000 & 0 & - & 0 \\
\hline & Osaka & 32 & 0 & - & 0 & - & - & 32 & 1.000 & 0 & - & 0 \\
\hline & Aichi & $\begin{array}{c}71 \\
(70.0) \\
\end{array}$ & $(1.0)$ & - & $\begin{array}{c}0 \\
(0.0) \\
\end{array}$ & - & 一 & 72 & 0.993 & 0.007 & - & 0.014 \\
\hline \multirow[t]{3}{*}{$G p i-2$} & Okayama & $\begin{array}{l}0 \\
(0.0)\end{array}$ & $\left(\begin{array}{l}1 \\
1.0\end{array}\right)$ & $\begin{array}{l}0 \\
(0.0)\end{array}$ & $\begin{array}{c}78 \\
(78.0)\end{array}$ & $\left(\begin{array}{l}1 \\
1.0)\end{array}\right.$ & $\begin{array}{c}0 \\
(0.0)\end{array}$ & 80 & 0.006 & 0.988 & 0.006 & 0.013 \\
\hline & Osaka & 0 & 0 & 0 & 32 & 0 & 0 & 32 & 0 & 1.000 & 0 & 0 \\
\hline & Aichi & 0 & 0 & 0 & 72 & 0 & 0 & 72 & 0 & 1.000 & 0 & 0 \\
\hline \multirow[t]{3}{*}{$I d h$} & Okayama & $\begin{array}{l}0 \\
(0.2)\end{array}$ & $\begin{array}{l}7 \\
(6.7)\end{array}$ & $\left(\begin{array}{l}0 \\
0.0\end{array}\right)$ & $\begin{array}{l}72 \\
(72.2)\end{array}$ & $\left(\begin{array}{l}1 \\
0.9\end{array}\right)$ & $\begin{array}{c}0 \\
(0.0)\end{array}$ & 80 & 0.044 & 0.950 & 0.006 & 0.002 \\
\hline & Osaka & $\begin{array}{l}\mathbf{0} \\
(\mathbf{0} .0)\end{array}$ & $(1.0)$ & $\begin{array}{l}0 \\
(0.0)\end{array}$ & $\begin{array}{l}30 \\
(30.0)\end{array}$ & $\left(\begin{array}{l}1 \\
1.0\end{array}\right)$ & $\begin{array}{l}0 \\
(0.0)\end{array}$ & 32 & 0.016 & 0.969 & 0.016 & 0.033 \\
\hline & Aichi & $\begin{array}{l}0 \\
(0.0) \\
\end{array}$ & $\left(\begin{array}{l}1 \\
1.0\end{array}\right)$ & - & $\begin{array}{c}71 \\
(71.0) \\
\end{array}$ & - & - & 72 & 0.007 & 0.993 & - & 0.004 \\
\hline \multirow[t]{3}{*}{$M d h-1$} & Okayama & $\left(\begin{array}{l}1 \\
0.1\end{array}\right)$ & $\begin{array}{l}3 \\
(4.8)\end{array}$ & - & $\begin{array}{c}76 \\
(75.1)\end{array}$ & - & - & 80 & 0.031 & 0.969 & - & 0.061 \\
\hline & Osaka & 0 & 0 & - & 32 & - & - & 32 & 0 & 1.000 & - & 0 \\
\hline & Aichi & $\begin{array}{l}0 \\
0.0) \\
\end{array}$ & $\left(\begin{array}{l}1 \\
1.0\end{array}\right)$ & - & $\begin{array}{c}71 \\
(71.0) \\
\end{array}$ & - & - & 72 & 0.007 & 0.993 & - & 0.004 \\
\hline \multirow[t]{3}{*}{$M d h-3$} & Okayama & $\begin{array}{c}71 \\
(70.3)\end{array}$ & $\begin{array}{l}8 \\
(9.4)\end{array}$ & - & $\left(\begin{array}{l}1 \\
0.0\end{array}\right)$ & - & - & 80 & 0.938 & 0.063 & - & 0.035 \\
\hline & Osaka & $\begin{array}{l}29 \\
(29.0)\end{array}$ & $\left(\begin{array}{l}3 \\
2.9)\end{array}\right.$ & - & $\begin{array}{l}0 \\
(0.1)\end{array}$ & - & - & 32 & 0.953 & 0.047 & - & 0.077 \\
\hline & Aichi & $\begin{array}{l}71 \\
(71.0)\end{array}$ & $\left(\begin{array}{l}1 \\
1.0)\end{array}\right.$ & - & $\begin{array}{l}0 \\
(0.0) \\
\end{array}$ & - & - & 72 & 0.993 & 0.007 & - & 0.004 \\
\hline
\end{tabular}


Table 2. Continued

\begin{tabular}{|c|c|c|c|c|c|c|c|c|c|c|c|c|}
\hline \multirow{2}{*}{ Locus } & \multirow{2}{*}{ Locality } & \multicolumn{6}{|c|}{ Phenotype } & \multirow{2}{*}{$\mathbf{N}$} & \multicolumn{3}{|c|}{ Allelic frequency } & \multirow{2}{*}{$\mathrm{X}^{2}$} \\
\hline & & A & $\mathrm{AB}$ & $\mathrm{AC}$ & B & $\mathrm{BC}$ & $\mathrm{C}$ & & $A$ & $B$ & $C$ & \\
\hline \multirow[t]{3}{*}{ 6-Pgd } & Okayama & - & - & - & $\begin{array}{l}67 \\
(67.5)\end{array}$ & $\begin{array}{l}13 \\
(11.9)\end{array}$ & $\begin{array}{c}0 \\
(0.5)\end{array}$ & 80 & - & 0.919 & 0.081 & 0.626 \\
\hline & Osaka & - & - & - & $\begin{array}{l}26 \\
(26.3)\end{array}$ & $\begin{array}{l}6 \\
(5.4)\end{array}$ & $\begin{array}{c}0 \\
(0.3)\end{array}$ & 32 & - & 0.906 & 0.094 & 0.432 \\
\hline & Aichi & $\begin{array}{l}0 \\
(0.0)\end{array}$ & $\begin{array}{l}1 \\
0.9)\end{array}$ & $\begin{array}{l}0 \\
(0.1)\end{array}$ & $\begin{array}{l}57 \\
(57.8)\end{array}$ & $\begin{array}{l}14 \\
(12.5)\end{array}$ & $\begin{array}{l}0 \\
(0.7)\end{array}$ & 72 & 0.007 & 0.896 & 0.097 & 0.973 \\
\hline \multirow[t]{3}{*}{$P g m$} & Okayama & $\begin{array}{l}39 \\
(39.0)\end{array}$ & $\left(\begin{array}{l}1 \\
1.0\end{array}\right)$ & - & $\begin{array}{l}0 \\
\left(\begin{array}{l}0.0 \\
)\end{array}\right)\end{array}$ & - & - & 40 & 0.975 & 0.025 & - & 0.000 \\
\hline & Osaka & 32 & 0 & - & 0 & - & - & 32 & 1.000 & 0 & - & 0 \\
\hline & Aichi & 72 & 0 & - & 0 & - & - & 72 & 1.000 & 0 & - & 0 \\
\hline \multirow[t]{3}{*}{$S d h$} & Okayama & $\begin{array}{c}71 \\
(71.3)\end{array}$ & $\left(\begin{array}{l}9 \\
8.5)\end{array}\right.$ & - & $\begin{array}{l}0 \\
(0.3)\end{array}$ & - & - & 80 & 0.944 & 0.056 & - & 0.006 \\
\hline & Osaka & 32 & 0 & - & 0 & - & - & 32 & 1.000 & 0 & - & 0 \\
\hline & Aichi & 66 & 6 & - & 0 & - & - & 72 & 0.958 & 0.042 & - & 0.136 \\
\hline
\end{tabular}

Table 3. Summary of genic variability in black seabream based on electrophoretic analysis of 44 loci. The numbers in parenthesis are calculated based on $1 \%$ criterion for polymorphism.

\begin{tabular}{lccc}
\hline \multirow{2}{*}{ Items } & \multicolumn{3}{c}{ Locality } \\
\cline { 2 - 4 } & Okayama & Osaka & Aichi \\
\hline No. of samples & 80 & 32 & 72 \\
No. of loci & 44 & 44 & 44 \\
$\quad$ examined* & & & \\
No. of poly- & 16 & 11 & 14 \\
$\quad$ morphic loci & $(16)$ & $(11)$ & $(9)$ \\
Proportion of & 0.341 & 0.250 & 0.318 \\
polymorphic loci & $(0.341)$ & $(0.250)$ & $(0.205)$ \\
No. of alleles & 1.386 & 1.272 & 1.386 \\
per locus & $(1.386)$ & $(1.272)$ & $(1.136)$ \\
Heterozygosity: & & & \\
$\quad$ Observed $\left(\mathrm{H}^{\circ}\right)$ & 0.072 & 0.057 & 0.069 \\
Expected $\left(\mathrm{H}^{\mathrm{e}}\right)$ & $\mathbf{0 . 0 7 1}$ & 0.057 & 0.066 \\
$\mathrm{H}^{\circ} / \mathrm{H}^{\circ}$ & $\mathbf{1 . 0 1 4}$ & $\mathbf{1 . 0 0 0}$ & 1.045 \\
\hline
\end{tabular}

* 12 loci of sarcoplasmic proteins and 3 loci of hemoglobins were included.

zygosity in black seabream $(0.066)$ was relatively similar to the result obtained by Fujo and KaTo, ${ }^{18)}$ to rainbow trout population, ${ }^{1)}$ and to red seabream. ${ }^{15)}$

Table 3 shows the relatively high genic variability in black searbeam. Because the genic variability in the qualitative characters is an indicator of the genic variability throughout the genomes of the population. the high average of heterozygousity of this species shows the possibility of high additive genetic variance in quantitative traits which are important for genetic improvement in the future breeding study.

The values of $\mathrm{H}^{\circ} / \mathrm{H}^{e}$ were higher than 1 ranging from 1.000 to 1.014 , so that the possibility of inbreeding in wild black seabream population could not be considered.

\section{Geographical Differentiation}

The differentiations among localities were tested by chi-square values for heterogeneity (Table 4). In some alleles, differences between two locations were significant in some cases, such as alleles $\mathrm{A}$ and $\mathrm{C}$ of Est-1, Idh and $M d h-3$ loci for Okayama vs. Aichi, and also $\alpha-G d h-1$ and 6-Pgd for Okayama vs. Osaka. These differences found in some loci between Okayama and other locations indicated that the population of Okayama may be independent.

F-statistics $\left(\mathrm{F}_{\mathrm{ST}}\right)^{17)}$ computation for each polymorphic enzyme are provided in Table 5. The average value of $F_{\mathrm{ST}}$ in black seabream was 0.0094 , ranging from 0.005 to 0.0327 . This average value of $F_{S T}$ in black seabream was smaller than those of blue gill Lepomis macrochirus $^{18)}$ and milkfish Chanos chanos. ${ }^{193}$ This small value of $F_{\mathrm{sT}}$ indicated that there were very small differentiation among localities in the population of black seabream examined here.

The values of genetic distance $(D)^{20)}$ were as follows: Okayama vs. Osaka 0.0018; Okayama vs. Aichi 0.0012; and Osaka vs. Aichi 0.0016. The $\mathrm{D}$ values between localities of black seabream were lower than milkfish, ${ }^{19)}$ and far smaller than chum salmon Oncorhynchus keta population of North America ${ }^{21}$, Coregonus albula populations in Finland, ${ }^{22}$ blue gill populations in Florida Lakes, ${ }^{18)}$ endemic arctic char Salvelinus alpinus populations from eastern United States and Canada, ${ }^{23)}$ and skipjack tuna Katsuwonus pelamis populations of Pacific Ocean. ${ }^{24)}$ The very small 
Table 4. Chi-square values for heterogeneity tests in polymorphic loci between two localities of black seabream. Significant values were marked by asteriscs

\begin{tabular}{|c|c|c|c|c|c|c|c|c|c|c|}
\hline \multirow{2}{*}{ Locus } & \multicolumn{2}{|c|}{$A d h$} & \multirow{2}{*}{$C k$} & \multicolumn{3}{|c|}{ Est-1 } & \multirow{2}{*}{$E s t-2$} & \multirow{2}{*}{$\alpha-G d h-1$} & \multirow{2}{*}{$\alpha-G d h-2$} & \multirow{2}{*}{$I d h$} \\
\hline & $B$ & $C$ & & $A$ & $B$ & $C$ & & & & \\
\hline $\begin{array}{l}\text { Okayama vs. } \\
\text { Osaka }\end{array}$ & 0.916 & 0.034 & 2.181 & 0.512 & 0.000 & 0.574 & 0.970 & $4.851^{*}$ & 0.000 & 0.377 \\
\hline $\begin{array}{l}\text { Okayama vs. } \\
\text { Aichi }\end{array}$ & 0.325 & 0.239 & 2.453 & $8.293^{* *}$ & 2.357 & $5.200^{*}$ & 0.298 & 1.599 & 1.115 & $4.890^{*}$ \\
\hline Osaka vs. Aichi & 0.205 & 0.351 & 0.447 & 2.202 & 1.189 & 0.991 & 0.518 & 1.830 & 0.447 & 1.841 \\
\hline
\end{tabular}

Table 4. Continued

\begin{tabular}{lcccccccccc}
\hline \multicolumn{1}{c}{ Locus } & $M d h-1$ & $M d h-3$ & $6-P g d$ & $P g m$ & $G p i-2$ & $S d h$ & $S p-1$ & $S p-2$ & $S p-3$ \\
\hline Okayama vs. Osaka & 2.046 & 0.204 & $6.275^{*}$ & 0.806 & $\mathbf{0 . 8 0 7}$ & $\mathbf{3 . 7 5 1}$ & 0.069 & 1.851 & 0.651 \\
Okayama vs. Aichi & 2.341 & $6.707^{* *}$ & 0.476 & 1.808 & 1.812 & 0.344 & 0.007 & 0.384 & 1.693 \\
Osaka vs. Aichi & 0.447 & 3.746 & 0.053 & 0.000 & 0.000 & 2.764 & 0.102 & 0.825 & 0.037 \\
\hline
\end{tabular}

*: $\mathrm{P}<0.05 * *$ : $\quad \mathbf{P}<0.01$

Table 5. F-statistics $\left(F_{S T}\right)$ values based on allelic frequencies in black seabream

\begin{tabular}{|c|c|c|c|c|c|c|}
\hline \multicolumn{2}{|c|}{ Locus/allele } & \multirow{2}{*}{$\frac{F_{\text {ST }}}{0.005}$} & \multicolumn{3}{|c|}{ Locus/allele } & \multirow{2}{*}{$\frac{F_{\mathrm{ST}}}{0.014}$} \\
\hline$A d h$ & $A$ & & $M d h-1$ & & $A$ & \\
\hline & $\mathrm{B}$ & 0.003 & $M d h-3$ & & $A$ & 0.015 \\
\hline & $C$ & 0.001 & 6-Pgd & & $A$ & 0.005 \\
\hline$C k$ & $A$ & 0.015 & & & $B$ & 0.001 \\
\hline \multirow[t]{3}{*}{ Est -1} & $A$ & 0.020 & & & $C$ & 0.001 \\
\hline & $B$ & 0.008 & $P g m$ & & $A$ & 0.017 \\
\hline & $C$ & 0.012 & $G p i-2$ & & $A$ & 0.004 \\
\hline$E s t-2$ & $A$ & 0.002 & & & $B$ & 0.002 \\
\hline \multirow[t]{3}{*}{$\alpha-G d h-1$} & $A$ & 0.005 & & & C & 0.004 \\
\hline & $B$ & 0.024 & $S d h$ & \% & $A$ & 0.033 \\
\hline & $C$ & 0.024 & $S_{p-1}$ & & $A$ & 0.001 \\
\hline$\alpha-G d h-2$ & $A$ & 0.005 & $s_{p-2}$ & & $A$ & 0.008 \\
\hline \multirow[t]{3}{*}{$I d h$} & $A$ & 0.011 & $S p-3$ & & $\boldsymbol{A}$ & 0.004 \\
\hline & $B$ & 0.011 & & & & \\
\hline & $C$ & 0.006 & & & & \\
\hline
\end{tabular}

values of $D$ in black seabream show that those populations are in a very close phenetic relationship.

\section{Acknowledgement}

The authors wish to thank to Dr. A. OchIAl, Professor of Kochi University for his encouragement. Thanks are also due to $\mathrm{Mr}$. S. Yamamoto of Okayama Prefectural Fisheries Experimental Station, Mr. T. Ishrwatari of Osaka Prefectural Fisheries Experimental Station, and Mr. K. IwASAKI of Aichi Prefectural Fisheries Experimental Station for supplying the fish samples.

\section{References}

1) F. W. Allendorf and F. M. Utter: in "Fish
Physiology" (ed. by W.S. HoAR and D.J. Randall), Vol. 8, Academic Press, New York, 1979, pp. 407-454.

2) R. MOAY, T. Brody, G. Wohlfarth, and G. Hulata: Aquaculture, 9, 217-228 (1976).

3) T. Brody, R. Moay, Z. V. Abramson, G. Hulata, and G. Wohlfarth: Aquaculture, 9, 351-365 (1976).

4) T. Brody, N. Storch, D. Kirsht, G. Hulata, G. WOHLfarth, and R. MOAV: Aquaculture, 20, 371-379 (1980).

5) J. D. MCIntyre and A. K. Johnson: Prog. Fish. Cult., 39, 175-177 (1977).

6) N. Taniguchi, R. Hamada, and H. Fujiwara: Bull. Japan. Soc. Sci. Fish., 47, 731-734 (1981).

7) N. TaniguchI and K. NumaChI: Bull. Soc. Sci. Fish., 44, 1351-1355 (1978).

8) N. Taniguchi, K. Sumantadinata, A. Suzuki, and J. YAMAda: Bull. Japan. Soc. Sic. Fish, 48, 139-141 (1982).

9) C. R. Shaw and R. Prasad: Biochem. Genet., 4, 297-320 (1970).

10) N. Taniguchi, Y. Okada, and Y. MiYazaki: Rept. Fish. Lab. Kochi Univ., 3, 19-30 (1978).

11) K. Numachi: Bull. Japan. Soc. Sci. Fish., 36, 1967-1977 (1970).

12) F. J. Ayala, J. R. Powell, M, L. Tracey, C. A. MOURAO, and S. Ferez-SAlYs: Genetics, 70, 113139 (1972).

13) R. C. Lundstrom: J. Assoc. Off. Anal. Chem., 63, 69-73 (1980).

14) M. Nishida, and Y. TAKaHASHI: Bull. Japan. Soc. Sci. Fish., 44, 1059-1064 (1978).

15) N. Taniguchi and Y. OKada: Bull. Japan. Soc. Scl. Fish., 46, 437-443 (1980).

16) Y. FuJio and Y. Kato: Bull. Japan. Soc. Sci. Fish., 45, 1169-1178 (1979).

17) M. NEI: Ann. Hum. Genet, Lond, 41, 225-233 (1977). 
18) J. D. Felley and J. C. Ayise: Trans, Am. Fish. Soc., 109, 108-115 (1980).

19) G. A. Winans: Evolution, 34, 558-574 (1980).

20) M. NEr: The American Naturalist, 106, 283-292 (1972).

21) T. OKazakI: Bull. Japan. Soc. Sci. Fish., 47, 507-514 (1981).
22) J. Vuorinen, M. K. J. Himberg, and P. LANKINEN: Hereditas, 94, 113-121 (1981).

23) I. Kornkfield, K. F. Beland, J. R. MoRing, and F.W. KIrcheIs: Can. J. Fish. Aquat. Sci, 38, 32-39 (1981).

24) K. Fujno, K. SASAKI, and S. OKumUra: Bull. Japan. Soc. Sci. Fish., 47, 215-222 (1981). 